Bull. Fac. Agric., Cairo Univ.,64: 332-339 (2013).

\title{
EFFECT OF SOME HERBICIDES ON ANNUAL GRASS \\ AND BROAD LEAVED WEEDS IN MAIZE CROP
}

2- Phytotoxic effect of some herbicides on maize crop

(Received:1.10.2013)

\author{
By \\ A. S. Marzouk \\ Phytotoxicity Department, Central, Agricultural Pesticides Laboratory, \\ Agricultural Research Center, Giza, Egypt.
}

\begin{abstract}
Two trials were conducted during 2010 and 2011 summer seasons in Tahanoub area, Qualubia Governorate, Egypt, to evaluate the phytotoxic effect of different doses of the new selective herbicide Equip $22.5 \%$ OD (foramsulfuron + isoxadifen-ethyl) against annual grassy and broad leaved weeds in maize (Zea mays L.) fields compared to the recommended herbicide by the Egyptian Ministry of Agriculture; Starane $20 \%$ EC (fluroxypyr) and manual hoeing. The results showed that when Equip was applied at the recommended dose $(750 \mathrm{cc} / \mathrm{fed}$.), it increased chlorophyll a, b and the total chlorophyll content of the treated maize leaves significantly compared with the other treatments at 7, 14 and 21 days after treatment (DAT) during the two growing seasons. When Equip was tested at the double rate it showed a significant reduction in the total chlorophyll content compared to the other treatments.

Data showed that Equip at the recommended rate as well as hoeing treatment increased maize shoot dry weight significantly compared to Equip applied at the double dose and the untreated check. Also, Equip at the recommended rate increased cob weight significantly more than the other treatments and recorded the highest cob weight being 363 and $170.71 \mathrm{~g} / \mathrm{cob}$ followed by hoeing $(352.5$ and $146 \mathrm{~g} / \mathrm{cob})$ and Starane $(310$ and $129.71 \mathrm{~g} / \mathrm{cob}$ ), at the $1^{\text {st }}$ and the $2^{\text {nd }}$ season, respectively, while Equip at the double dose showed the lowest significant effect.
\end{abstract}

Key words: Equip $22.5 \%$ OD, phytotoxicity, maize (Zea mays L.).

\section{INTRODUCTION}

Maize (Zea mays L.) is sensitive to weeds especially in the early growth stages. (Cheema et al., 2004; Baghestani et al., 2007). Indiscriminate use of chemicals for controlling weeds may pose environmental problems (Cheema \& Khaliq, 2000). Although herbicides are very effective in controlling weeds, certain risks as environmental pollution and human health are involved in herbicide use.

Previously, many studies revealed that the phytotoxicity of sulfonylurea herbicide group increased with increasing the concentration in soil. (Eleni Kotoula et al., 1993). Moreover, the phytotoxicity may occur to the susceptible species at levels as low as $0.1 \mathrm{~g} / \mathrm{h}$ because of their great mobility in the soil and long persistence. Also, they can damage following crops for several growing seasons, (Cotterill (1992). Hollaway et al., (2006), mentioned that sulfonylurea herbicides in alkaline soils ( $\mathrm{pH}$ range 7.4 - 8.6) persisted for 3-5 years which is long enough to damage subsequent rotational crops.

Foramsulfuron is a new selective sulfonylurea herbicide that inhibits acetolactate syntheses key enzme in its branched chain amino acid synthesis (ALS or AHAS). Excellent crop safety was exhibited and crop response was minimal because of the proprietary safener isoxadifen-ethyl which is formulated with foramsulfuron. Previous research has shown that isoxadifen-ethyl reduces foramsulfuron phytotoxicity in maize by increasing the rate of foramsulfuron degradation (Chad et al., 2001). Isoxadifen-ethyl has also been shown to reduce phytotoxicity of several broadleaf herbs. Also, the safener of isoxadifen-ethyl increased parent foramsulfuron selectivity by reducing its 
translocation to the grown maize (Pesticide Manual, 2003-2004)

The present study aimed to evaluate the phytotoxicity of foramsulfuron to maize plants in comparison with the recommended maize herbicide under Egyptian field conditions.

\section{MATERIAL AND METHODS}

\subsection{Field preparation and experiment design}

Two trials were conducted during 2010 and 2011 summer season in Tahanoub area, Qualubia Governorate, Egypt, to evaluate the phytotoxic effect of the new herbicide foramsulfuron at different doses against maize (Zea mays L.) plants compared to Starane as the standard herbicide recommended by the Egyptian Ministry of Agriculture. All treatments were laid out in a randomized complete block design with three replications as well as the untreated check (control). The net plot size was $54 \mathrm{~m}^{2}$. Hagen 2030 (hybrid) maize was planted. The analysis indicated that the soil was silty clay with particle size distribution $0.0 \%$ sand, $61 \%$ silt and $39 \%$ clay. Some of the physico-chemical characteristics and organic matter content (OM) of the used soil are presented in Table (1). week after spraying, the visual phytotoxic symptoms i.e., yellowing, stunting, malformation, burning, necrosis and leaf curl were observed in all treated plots. Also, chlorophyll a $\left(\mathrm{Chl}_{\mathrm{a}}\right)$, Chlorophyll $\mathrm{b}\left(\mathrm{Chl}_{\mathrm{b}}\right)$ and the total chlorophyll $\left(\mathrm{Chl}_{\mathrm{t}}\right)$ were determined periodically 7 days after application.

Chlorophyll a, $\mathrm{Chl}_{\mathrm{b}}$ and $\mathrm{Chl}_{\mathrm{t}}$ were calculated using Arnon equation (1949).

Chl. ${ }_{\mathrm{a}}=12.7 \times$ O.D $662-2.69 \times$ O.D $644 \mathrm{mg} / \mathrm{l}$

Chl. b $=22.9 \times$ O.D $644-2.69 \times$ O.D $662 \mathrm{mg} / 1$

Chl. ${ }_{\mathrm{t}}=20.2 \times$ O.D $644+8.02 \times$ O.D $662 \mathrm{mg} / \mathrm{l}$

At the harvest stage, maize plant height, dry and fresh weight (g/plant) were oven dried at $72{ }^{\circ} \mathrm{C}$ for 48 h., cob number/plant and cob weight for each treatment was recorded.

2.4. Statistical analysis: The crop parameters were analyzed statistically by using SPSS analysis of variance technique and least significant difference test was applied at $5 \%$ probability level to compare treatment means.

\section{RESULTS AND DISCUSSION}

\subsection{Phytotoxicity symptoms}

Over all the experiment time, the visual phytotoxic symptoms, i.e. yellowing, stunting, malformation, burning, necrosis and leaf curl were

Table (1): Physico-chemical characteristics of the used soil.

\begin{tabular}{|c|c|c|c|c|c|c|c|c|c|c|}
\hline pH & EC & \multicolumn{4}{|c|}{ Soluble cations (meq/l) } & \multicolumn{3}{|c|}{ Soluble anions (meq/l) } & \multirow{2}{*}{$\underset{\%}{\text { O.M }}$} & \multirow{2}{*}{$\begin{array}{l}\text { SP } \\
\% *\end{array}$} \\
\hline $\begin{array}{l}(1: 2.5) \\
\text { Suspen }\end{array}$ & $\frac{\mathrm{dsm}^{-1}}{\text { at } 25 \mathrm{C}}$ & $\mathrm{Ca}^{++}$ & $\mathbf{M g}^{++}$ & $\mathbf{K}^{+}$ & $\mathbf{N a}^{+}$ & $\mathrm{HCO}_{3}^{-}$ & $\mathrm{Cl}^{-}$ & $\mathrm{SO}_{4}^{--}$ & & \\
\hline 7.2 & 6.9 & 37.84 & 20.3 & 1.6 & 21.74 & 4.25 & 26.56 & 50.67 & 1.96 & 53.33 \\
\hline
\end{tabular}

* Saturation percentage.

\subsection{Herbicide treatment}

The herbicides were sprayed 3 weeks after planting using knapsack hand sprayer with flat fan nozzle at field capacity condition. Hand hoeing was conducted twice after the $1^{s t}$ and the $2^{\text {nd }}$ irrigation. All other agricultural practices were kept as used for all treatments.

Equip $22.5 \%$ OD (foramsulfuron + isoxadifenethyl) at the recommended rate $(750 \mathrm{cc} / \mathrm{fed}$.), and at the double rate $(1500 \mathrm{cc} / \mathrm{fed}$.), and Starane $20 \%$ EC (fluroxypyr) were applied at the rate of $200 \mathrm{cc} / \mathrm{fed}$. The treated and untreated check were replicated 3 times distributed in completely randomized plots.

\subsection{Measurements of phytotoxic action}

The phytotoxic effect of the treated herbicide was carried out according to FAO, (2006). One observed at the different herbicide types/rates treatments.

\subsection{Chlorophyll content}

Data presented in Table (2) showed that Equip at the recommended rate $(750 \mathrm{cc} / \mathrm{fed}$.), increased the average of $\mathrm{Chl}_{\mathrm{a}}, \mathrm{Chl}_{\mathrm{b}}$, and $\mathrm{Chl}_{\mathrm{t}}$ content significantly compared to the other treatments after 7, 14, 21 days from application during the two seasons.

\subsection{Chlorophyll a contents}

The present results showed that maize leaf $\mathrm{Chl}_{\mathrm{a}}$ varied significantly according to the applied treatment and the application rate of herbicides during the two growing seasons.

The data showed that Equip at the recommended dose increased $\mathrm{Chl}_{\mathrm{a}}$ significantly than the other treatments followed by hoeing and recorded the 
highest content after 7, 14 and 21 days from application (DAT), being 5.99, 4.66 and $5.65 \mathrm{mg} / \mathrm{g}$ fresh weight, and $2.88,3.06$ and $2.92 \mathrm{mg} / \mathrm{g}$ fresh weight at the $1^{\text {st }}$ and the $2^{\text {nd }}$ season, respectively.

However, when the recommended dose was doubled, $\mathrm{Chl}_{\mathrm{a}}$ decreased significantly compared to Equip at the recommended rate recording the lowest content after 7 and 21 DAT being 3.16 and 2.59 $\mathrm{mg} / \mathrm{g}$ fresh weight, and 2.88 and $2.92 \mathrm{mg} / \mathrm{g}$ fresh weight, at the $1^{\text {st }}$ and the $2^{\text {nd }}$ season, respectively.

Starane treatment significantly decreased $\mathrm{Chl}_{\mathrm{a}}$ compared to Equip at the recommended rate after 7 and 21 DAT during the $1^{\text {st }}$ and $2^{\text {nd }}$ season reaching 4.3 and $3.373 \mathrm{mg} / \mathrm{g}$ fresh weight, or 2.06 and 1.85 $\mathrm{mg} / \mathrm{g}$ fresh weight, respectively.

Equip at the double rate, Starane and hoeing treatments showed inconsistent un-uniform response after 14 DAT.

\subsection{Chlorophyll b contents}

The data presented in Table (2) showed a correlation between the change of $\mathrm{Chl}_{\mathrm{a}}$ and $\mathrm{Chl}_{\mathrm{b}}$ contents in maize leaves.

The data showed that Equip at the recommended dose increased $\mathrm{Chl}_{\mathrm{b}}$ significantly compared to the other treatments after 7, 14 and 21 DAT, reaching $1.08,0.9$ and $0.97 \mathrm{mg} / \mathrm{g}$ fresh weight, and $2.52,2.64$ and $2.42 \mathrm{mg} / \mathrm{g}$ fresh weight during the $1^{\text {st }}$ and the $2^{\text {nd }}$ season, respectively.

When Equip dose was doubled, it showed significant decrease in $\mathrm{Ch}_{\mathrm{b}}$ content compared to the other treatments after 7 and 21 DAT, recording the lowest content being 0.36 , and $0.37 \mathrm{mg} / \mathrm{g}$ fresh weight or 1.71 and $1.69 \mathrm{mg} / \mathrm{g}$ fresh weight, during the first and the second growing seasons, respectively.

Hoeing treatment showed no significant effect compared with Equip at the recommended dose after 7 and 21 DAT, while Starane showed fluctuated effect on $\mathrm{Chl}_{\mathrm{b}}$ content compared to the other treatments during the two seasons.

\subsection{Total chlorophyll contents}

The data presented in Table (2) showed that the change of the total chlorophyll of maize leaves synchronizes with the variation in $\mathrm{Chl}_{\mathrm{a}}$ and $\mathrm{Chl}_{\mathrm{b}}$ according to applied treatment during the growing two seasons.

The results showed that Equip applied at the recommended dose, significantly increased $\mathrm{Chl}_{\mathrm{t}}$ content comported to the other treatments reaching, $7.07,5.56$ and $6.62 \mathrm{mg} / \mathrm{g}$ fresh weight, or 5.40, 5.70 and $5.33 \mathrm{mg} / \mathrm{g}$ fresh weight after 7,14 and 21 DAT during the $1^{\text {st }}$ and $2^{\text {nd }}$ growing seasons, respectively.

Equip applied at the double rate significantly decreased $\mathrm{Chl}_{\mathrm{t}}$ after 7 and $21 \mathrm{DAT}$ and it was less than all other treatments being, 3.52 and $2.96 \mathrm{mg} / \mathrm{g}$ fresh weight and 4.17 and $3.95 \mathrm{mg} / \mathrm{g}$ fresh weight at the $1^{\text {st }}$ and $2^{\text {nd }}$ growing seasons, respectively.

Hoeing treatment showed no significant effect on $\mathrm{Chl}_{\mathrm{t}}$ compared to Equip at the recommended dose. It increased the total chlorophyll content after 7 and $14 \mathrm{DAT}$, reaching 5.84 and $6.40 \mathrm{mg} / \mathrm{g}$ fresh weight at the $1^{s t}$ season, and 5.07 and $4.95 \mathrm{mg} / \mathrm{g}$ fresh weight at the $2^{\text {nd }}$ season, respectively.

\subsection{Chlorophyll a/b ratio}

The results in Table (2) indicated that chlorophyll $\mathrm{a} / \mathrm{b}$ ratio showed no marked differences between the different treatments during the two growing seasons, except Equip treatments when applied at the double dose which increased chlorophyll $\mathrm{a} / \mathrm{b}$ ratio markedly comparing to the other treatments after 7 and 21 DAT.

\subsection{Shoot weight and height}

\subsubsection{Shoot height}

The data in Tables ( 3 and 4 ) revealed that hoeing increased maize height significantly $(250 \mathrm{~cm})$ compared with Equip applied at the double dose $(221.5 \mathrm{~cm})$ and the untreated check $(216 \mathrm{~cm})$ at the $1^{s t}$ season, while there was no significant difference between the other treatments.

All treatments and the untreated control showed no significant effect on maize plant height during the $2^{\text {nd }}$ season.

\subsubsection{Fresh weight}

The results in Tables ( 3 and 4) illustrated that all treatments showed no significant differences in shoot fresh weight, while it was significantly increased in the $1^{\text {st }}$ and the $2^{\text {nd }}$ seasons compared with the untreated check.

\subsubsection{Dry weight}

Data presented in Tables (3 and 4), showed no significant differences between Equip at the recommended rate and hoeing treatment being $320.83 \mathrm{~g}$ and $320.0 \mathrm{~g}$ at the $1^{\text {st }}$ season and 165.42 and $156.42 \mathrm{~g}$ at the $2^{\text {nd }}$ season, respectively. When Equip was applied at the double rate it showed no significant effect on shoot dry weight $(260 \mathrm{~g})$ compared to the untreated control $(265 \mathrm{~g})$ in the $1^{s t}$ season, or 119.64 and $125 \mathrm{~g}$ in the $2^{\text {nd }}$ season, respectively. There was no significant differences between Starane and hoeing treatment during the two growing seasons.

\subsubsection{Fresh/dry weight ratio}


Table (2): Effect of Equip 22.5 OD at two doses and Starane on maize leaf chlorophyll Content (mg/g fw).

\begin{tabular}{|c|c|c|c|c|c|c|c|c|c|c|}
\hline \multirow[b]{2}{*}{$\begin{array}{l}\text { Days after } \\
\text { treatment }\end{array}$} & \multicolumn{2}{|c|}{ Treatment } & \multicolumn{3}{|c|}{ First season } & \multirow[b]{2}{*}{ Chl a/b } & \multicolumn{3}{|c|}{ Second season } & \multirow[b]{2}{*}{ Chl a/b } \\
\hline & Herbicide & $\begin{array}{c}\text { Rate of Appl. } \\
\text { CC /fed. }\end{array}$ & Chl a & Chl b & Chl t & & Chl a & Chl b & Chl t & \\
\hline \multirow{6}{*}{7} & Equip22.5 OD & 750 & $5.99 \mathrm{a}$ & $1.08 \mathrm{a}$ & $7.07 \mathrm{a}$ & 5.55 & $2.88 \mathrm{a}$ & $2.52 \mathrm{a}$ & $5.40 \mathrm{a}$ & 1.14 \\
\hline & Equip 22.5 OD & 1500 & $3.16 \mathrm{c}$ & $0.36 \mathrm{c}$ & $3.52 \mathrm{c}$ & 8.78 & $2.46 \mathrm{~b}$ & $1.71 \mathrm{c}$ & $4.17 \mathrm{~b}$ & 1.44 \\
\hline & $\begin{array}{c}\text { Starane 20\% } \\
\text { EC } \\
\end{array}$ & 200 & $4.30 \mathrm{~b}$ & $0.70 \mathrm{~b}$ & $5.00 \mathrm{~b}$ & 6.14 & $2.47 \mathrm{~b}$ & $2.06 \mathrm{~b}$ & $4.53 \mathrm{~b}$ & 1.20 \\
\hline & Manual hoeing & Twice & $5.0 \mathrm{ab}$ & $0.84 \mathrm{ab}$ & $5.84 \mathrm{ab}$ & 5.95 & $2.62 \mathrm{ab}$ & $2.45 \mathrm{a}$ & $5.07 \mathrm{a}$ & 1.07 \\
\hline & Control & ----- & $3.82 \mathrm{c}$ & $0.70 \mathrm{~b}$ & $4.52 \mathrm{bc}$ & 5.46 & $2.48 \mathrm{~b}$ & $2.16 \mathrm{~b}$ & $4.64 \mathrm{~b}$ & 1.15 \\
\hline & LSD & & 1.08 & 0.3 & 1.52 & & 0.29 & 0.29 & 0.41 & \\
\hline \multirow{6}{*}{14} & Equip22.5 OD & 750 & $4.66 \mathrm{a}$ & $0.90 \mathrm{a}$ & $5.56 \mathrm{a}$ & 5.18 & $3.06 \mathrm{a}$ & $2.64 \mathrm{a}$ & $5.70 \mathrm{a}$ & 1.16 \\
\hline & Equip 22.5 OD & 1500 & $\begin{array}{c}3.82 \\
\mathrm{ab}\end{array}$ & $0.58 \mathrm{~b}$ & $4.40 \mathrm{a}$ & 6.59 & $2.16 \mathrm{~b}$ & $1.66 \mathrm{~b}$ & $3.82 \mathrm{~b}$ & 1.30 \\
\hline & $\begin{array}{c}\text { Starane } 20 \% \\
\text { EC } \\
\end{array}$ & 200 & $4.35 \mathrm{a}$ & $0.79 \mathrm{ab}$ & $5.14 \mathrm{a}$ & 5.51 & $2.79 \mathrm{a}$ & $2.31 \mathrm{a}$ & $5.10 \mathrm{a}$ & 1.21 \\
\hline & Manual hoeing & Twice & $2.75 \mathrm{~b}$ & $0.35 \mathrm{c}$ & $3.10 \mathrm{~b}$ & 7.86 & $2.12 \mathrm{~b}$ & $1.73 \mathrm{~b}$ & $3.85 \mathrm{~b}$ & 1.23 \\
\hline & Control & ----- & $2.39 \mathrm{~b}$ & $0.37 \mathrm{c}$ & $2.76 \mathrm{~b}$ & 6.46 & $1.60 \mathrm{c}$ & $1.39 \mathrm{~b}$ & $2.99 \mathrm{c}$ & 1.15 \\
\hline & LSD & & 1.08 & 0.25 & 1.18 & & 0.36 & 0.35 & 0.7 & \\
\hline \multirow{6}{*}{21} & Equip22.5 OD & 750 & $5.65 \mathrm{a}$ & $0.97 \mathrm{a}$ & $6.62 \mathrm{a}$ & 5.82 & $2.92 \mathrm{a}$ & $2.41 \mathrm{a}$ & $5.33 \mathrm{a}$ & 1.21 \\
\hline & Equip 22.5 OD & 1500 & $2.59 \mathrm{~b}$ & $0.37 \mathrm{c}$ & $2.96 \mathrm{c}$ & 7.00 & $2.26 \mathrm{~b}$ & $1.69 \mathrm{~b}$ & $3.95 \mathrm{~b}$ & 1.34 \\
\hline & $\begin{array}{c}\text { Starane 20\% } \\
\text { EC } \\
\end{array}$ & 200 & $3.37 \mathrm{~b}$ & $0.63 \mathrm{~b}$ & $4.00 \mathrm{~b}$ & 5.35 & $2.36 \mathrm{~b}$ & $1.85 \mathrm{~b}$ & $4.21 \mathrm{~b}$ & 1.28 \\
\hline & Manual hoeing & Twice & $5.52 \mathrm{a}$ & $0.88 \mathrm{a}$ & $6.40 \mathrm{a}$ & 6.27 & $2.74 \mathrm{a}$ & $2.21 \mathrm{a}$ & $4.95 \mathrm{a}$ & 1.24 \\
\hline & Control & ----- & $4.90 \mathrm{a}$ & $0.90 \mathrm{a}$ & $5.80 \mathrm{a}$ & 5.44 & $2.43 \mathrm{~b}$ & $1.88 \mathrm{~b}$ & $4.31 \mathrm{~b}$ & 1.29 \\
\hline & LSD & & 0.79 & 0.17 & 0.89 & & 0.23 & 0.27 & 0.46 & \\
\hline
\end{tabular}

The figures followed by the same letters are insignificant. 
Table (3): Effect of Equip 22.5 OD at two doses and Starane on maize plant characteristics at the first season.

\begin{tabular}{|c|c|c|c|c|c|c|c|}
\hline \multicolumn{2}{|c|}{ Treatment } & \multirow{2}{*}{$\begin{array}{c}\text { Plant } \\
\text { height } \\
(\mathbf{c m})\end{array}$} & \multicolumn{2}{|c|}{ Shoot Weight } & \multirow{2}{*}{$\begin{array}{c}\text { Fw / Dw } \\
\text { ratio }\end{array}$} & \multicolumn{2}{|c|}{ Cobs } \\
\hline Herbicide & $\begin{array}{c}\text { Rate of Appl. } \\
\text { CC /fed. }\end{array}$ & & fw $(g)$ & dw $(g)$ & & $\begin{array}{c}\text { Cob No./ } \\
\text { plant }\end{array}$ & $\begin{array}{c}\text { Weight/Cob } \\
\text { (g) }\end{array}$ \\
\hline Equip22.5 OD & 750 & $226.0 \mathrm{ab}$ & $480.0 \mathrm{ab}$ & $320.83 \mathrm{a}$ & 1.5 & $2.2 \mathrm{a}$ & $363.0 \mathrm{a}$ \\
\hline Equip 22.5 OD & 1500 & $221.5 \mathrm{~b}$ & $535.0 \mathrm{a}$ & $260.0 \mathrm{~b}$ & 2.1 & $2.1 \mathrm{a}$ & $235.0 \mathrm{~b}$ \\
\hline Starane $20 \%$ EC & 200 & $235.5 \mathrm{ab}$ & $580.0 \mathrm{a}$ & $300.0 \mathrm{ab}$ & 1.9 & $2.1 \mathrm{a}$ & $310.0 \mathrm{a}$ \\
\hline Manual hoeing & Twice & $250.0 \mathrm{a}$ & $590.0 \mathrm{a}$ & $320.00 \mathrm{a}$ & 1.8 & $2.2 \mathrm{a}$ & $352.5 \mathrm{a}$ \\
\hline Control & & $216.0 \mathrm{~b}$ & $390.0 \mathrm{~b}$ & $265.0 \mathrm{~b}$ & 1.5 & $2.1 \mathrm{a}$ & $232.5 \mathrm{~b}$ \\
\hline LSD & & 23.45 & 113.36 & 42.02 & & 0.33 & 70.23 \\
\hline
\end{tabular}

The figures followed by the same letters are insignificant .

Table (4): Effect of Equip 22.5 OD at two doses and Starane on maize plant characteristics at the second season.

\begin{tabular}{|c|c|c|c|c|c|c|c|}
\hline \multicolumn{2}{|c|}{ Treatment } & \multirow{2}{*}{$\begin{array}{c}\text { Plant } \\
\text { height } \\
(\mathrm{cm})\end{array}$} & \multicolumn{2}{|c|}{ Shoot Weight } & \multirow{2}{*}{$\begin{array}{c}\text { Fw / Dw } \\
\text { ratio }\end{array}$} & \multicolumn{2}{|c|}{ Cobs } \\
\hline Herbicide & $\begin{array}{c}\text { Rate of Appl. } \\
\text { CC /fed. }\end{array}$ & & fw $(g)$ & dw (g) & & $\begin{array}{c}\text { Cob No./ } \\
\text { plant }\end{array}$ & $\begin{array}{c}\text { Weight/Cob } \\
\text { (g) }\end{array}$ \\
\hline Equip22.5 OD & 750 & $146.4 \mathrm{a}$ & $219 \mathrm{bc}$ & $165.42 \mathrm{a}$ & 1.3 & $2.3 \mathrm{a}$ & $170.71 \mathrm{a}$ \\
\hline Equip 22.5 OD & 1500 & $140.6 \mathrm{a}$ & $247.0 \mathrm{~b}$ & $119.64 \mathrm{c}$ & 2.1 & $1.6 \mathrm{~b}$ & $95.57 \mathrm{c}$ \\
\hline Starane $20 \%$ EC & 200 & $159.2 \mathrm{a}$ & $249.0 \mathrm{~b}$ & $144.78 \mathrm{~b}$ & 1.7 & $1.9 \mathrm{ab}$ & $129.71 \mathrm{~b}$ \\
\hline Manual hoeing & Twice & $161.8 \mathrm{a}$ & $308.6 \mathrm{a}$ & $156.42 \mathrm{ab}$ & 2.0 & $2.0 \mathrm{ab}$ & $146.00 \mathrm{ab}$ \\
\hline Control & & $136.6 \mathrm{a}$ & $192.0 \mathrm{c}$ & $123.3 \mathrm{c}$ & 1.6 & $1.2 \mathrm{~b}$ & $89.00 \mathrm{c}$ \\
\hline LSD (0.05 ) & & 42.5036 & 42.412 & 13.3071 & & 0.6076 & 30.4608 \\
\hline
\end{tabular}

The figures followed by the same letters are insignificant . 
Data presented in Tables ( 3 and 4 ) indicated that all treatments showed no major differences in fresh/dry weight ratio between the different treatments during the two growing seasons. Equip at the double dose, Starane and the hoeing treatment increased fresh weight/dry weight ratio remarkably compared to the other treatments reaching $2.1,1.9$ and $1.8 \%$ at the $1^{\text {st }}$ season, and $2.1,1.7$ and $2.0 \%$ at the $2^{\text {nd }}$ season, respectively. In contiast, Equip at the recommended dose showed the lowest ratio being 1.5 and $1.3 \%$ during the $1^{\text {st }}$ and the $2^{\text {nd }}$ season, respectively.

\subsection{Cob number and weight}

Results in Tables (3 and 4) showed that all treatments revealed no significant effect on cob No./plant during the $1^{s t}$ season. At the $2^{\text {nd }}$ season, Equip at the recommended rate increased cob No./plant significantly being 2.3 followed by the hoeing treatment $(2$ cobs/plant) and Starane treatment (1.9 cobs/plant). Cob number was significantly reduced in Equip double rate treatment (1.6) and the untreated check (1.2).

Equip at the recommended rate, Starane and hoeing significantly increased cob weight being 363,310 and $352.5 \mathrm{~g} / \mathrm{cob}$ at the $1^{\text {st }}$ season, respectively. Equip at the double rate and the untreated control significantly decreased cob weight in the $1^{s t}$ season. In the $2^{\text {nd }}$ season, Equip, hoeing and Starane treatments significantly increased cob weight being $170.71,146$, and $129.71 \mathrm{~g} / \mathrm{cob}$, compared to $95.57,89 \mathrm{~g} / \mathrm{cob}$ when Equip dose was doubled and the untreated control, respectively.

No visual phytotoxicity symptoms over all the experiment time and increasing of $\mathrm{Ch}_{\mathrm{a}}, \mathrm{Ch}_{\mathrm{b}}$ and $\mathrm{Ch}_{\mathrm{t}}$ in Equip treatments could be attributed to the proprietary safener isoxadifen-ethyl that is formulated with foramsulfuron. Previous research showed that isoxadifen-ethyl reduced foramsulfuron phytotoxicity in corn by increasing the rate of foramsulfuron degradation (Chad et al., 2001). Isoxadifen-ethyl has also been shown to reduce phytotoxicity of several broadleaf herbicides.

Arnold et al., 2005, indicated that when nicosulfuron plus rimsulfuron, DPX 79406, and foramsulfuron were applied in combination with diflufenzopyr plus dicamba, dicamba plus atrazine, mesotrione, or dicamba, broadleaf weed control increased significantly without field corn injury or yield reductions.
Application of foramsulfuron caused injury to Corn at 7 DAT but did not exceed a rating of $10 \%$; by 14 and 28 DAT no corn injury was recorded, (Nurse et al., 2007).

Decreasing of maize height, dry weight, cob number and cob weight in the untreated control treatment comparing to the herbicide treatments could be attributed to the weed infestation which could reduce maize yield by approximately 77 and 64\% (Zaremohazabieh and Ghadiri, 2011). Also, Evans et al. (2001) reported that early season weed competition reduced kernel number. In contrast, Equip herbicide treatments showed that the high significant results comparing to the untreated control may be due to that foramsulfuron was the most effective herbicide for reducing weed density significantly in maize fields (Lotfi et al., 2012).

Latifil and Jamshidi (2011), showed that foramsulfuron significantly increased corn plant height, stem diameter, ear length, seed number per raw in the ear, seed number per ear, thousand kernel weight, seed yield, biological yield and chlorophyll content than the untreated check.

The above mentioned results are in agreement with Zaremohazabieh and Ghadiri,( 2011), who indicated that herbicide treatments had significant effect on maize grain yield and the highest maize grain yield were obtained with foramsulfuron at two applied rates $\left(0.03\right.$ and $0.06 \mathrm{~kg}$ a.i. $\left./ \mathrm{ha}^{-1}\right)$ as a result of herbicide reducing weed density and increased grain yield.

From the above mentioned results it could be concluded that foramsulfuron herbicide product formulated with the safener of isoxadifen-ethyl could be used safely at the recommended rate to protect maize field from weed infestation.

\section{REFERENCES}

Arnold R. N., Smeal, D., and O'Neill, M. K. (2005). Broadleaf weed control in field corn with postemergence herbicides. Online. Crop Management doi:10.1094/CM-2005-0224-01RS.

Arnon D.I. (1949).Copper enzymes in isolated chloroplasts, polyphenoloxidase in Beta vulgaris. Plant Physiology, 24 (1):1-15.

Baghestani M. A., Zand E., Soufizadeh S., Eskandari A., PourAzar R., Veysi M., and Nassirzadeh N.( 2007). Efficacy evaluation of some dual purpose herbicides to control 
weeds in maize (Zea mays L.). Crop Protection, 26: 936-942.

Chad E., Ken P. and Richard R. ( 2001). The effect of adjuvant on foramsulfuron and isoxadifenmethyl performance. In Proceedings of the North Central Weed Science Society.Vol. 56.

Cheema Z.A., Khaliq A. (2000). Use of sorghum allelopathic properties to control weeds in irrigated wheat in a semi arid region of Punjab. Agriculture, Ecosystems and Environment. 79: 105-112.

Cheema Z. A., Khaliq A., and Saeed S. (2004). Weed control in maize (Zea mays L.) through sorghum allelopathy. J. Sust. Agric., 23: 7386.

Cotterill E. G.(1992). Determination of the sulfonylurea herbicides chlorsulfuron and metsulfuron-methyl in soil, water and plant material by gas chromatography of their pentafluorobenzyl derivatives. Pest. Sci., 34 (3): 291-296.

Eleni Kotoula S., Eleftherohorinos I.G., Gagianasi A. A. and Sficasi A. G. (1993). Phytotoxicity and persistence of chlorsulfuron, metsulfuronmethyl, triasulfuron and tribenuron-methyl in three soils. Weed Research. 33(5): 355-367.

Evans J. O., Hauderlie P. and Williams R. W. (2001). Control of common lambsquarters in Roundup ready corn. W. Soc. Weed Sci. 2001 Res. Prog. Rep
FAO (2006). Guidelines on efficacy evaluation for the registration of plant protection products. 30-32.

Hollaway K. L., Kookana R. S., Noy D. M., Smith J. G. and Wilhelm N. (2006). Persistence and leaching of sulfonylurea herbicides over a 4year period in the highly alkaline soils of south-eastern Australia. Aust. J. of Exp. Agric., 46(8) 1069-1076

Latifil P. and Jamshidi S. (2011). Management of Corn Weeds by Broomcorn Sorgaab and Foramsulfuron Reduced Doses Integration. International Conference on Biology, Environment and Chemistry, IPCBEE vol.24 (2011) (C) (2011)IACSIT Press, Singapore.

Lotfi M., Daneshian J. and Baghestani M. (2012). Investigation of integrated weed management in Broomcorn (Sorghum bicolor) farms in Miyaneh region. J. of Agri. Sci. (univ. of Tabriz). 22(1): 55-70.

Nurse R. E., Hamill A. S., Swanton C. J., Tardif F. J. and Sikkema P. H. (2007). Weed Control and Yield Response to Foramsulfuron in Corn. Weed Tech. 21(2):453-458.

Pesticide Manual V. (3), 2003-2004.

Zaremohazabieh S. and Ghadiri H. (2011). Effects of Rimsulfuron, Foramsulfuron and Conventional Herbicides on weed control and maize yield at three planting dates. J. Biol. Environ. Sci. 5(14): 47-56.

\section{تأثير بعض مبيدات الحشائش على الحشائش الحولية النجيلية وعريضة الاوراق فى محصول الذرة

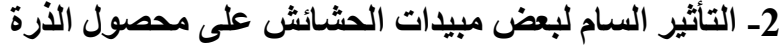

\section{علاء سعد مرزوق}

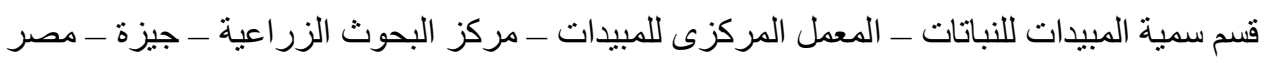

\section{ملخص}

تم إجراء هذه التجربة خلال الموسم الزراعى الصيفى 2011 ، 2012 بمنطقة طحانوب، بمحافظة القليوبية، مصر، لتقبيم

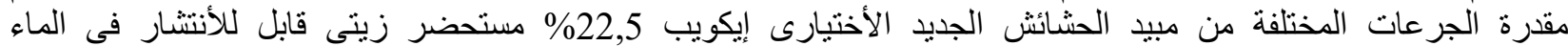

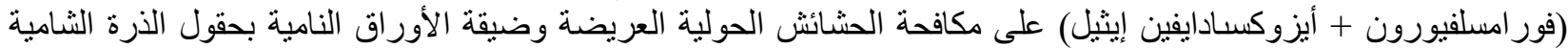

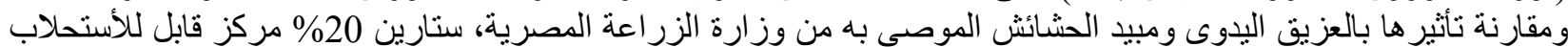
(فلوروكسيباير).

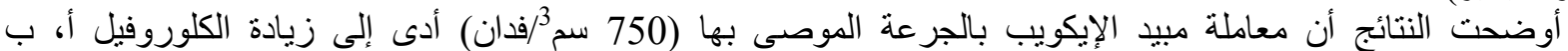

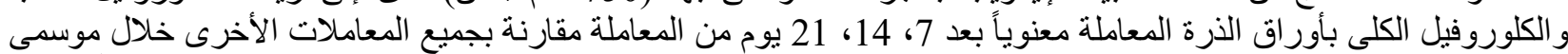

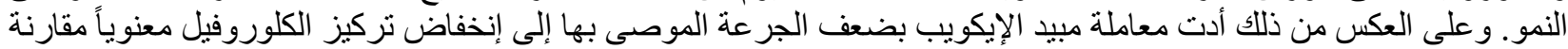

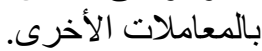




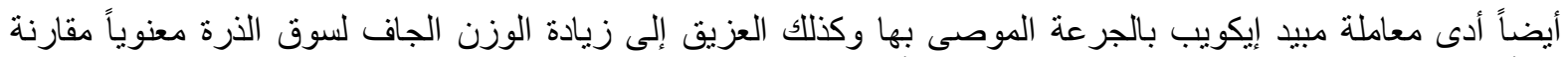

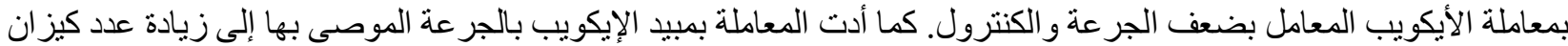

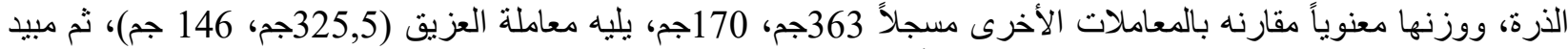

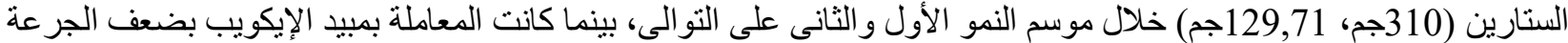
الأقل معنوياً. المجلة العلمية لكلية الزراعة - جامعة القاهرة - المجلد (64) العدد الثالث (يوليو2013):339-332 ـ 